Marija Marčetić ${ }^{1}$

Slađana Mušikić2

Belgrade Business Academy for Applied studies

Željko Dević3

Higher Economic School of Professional Studies Peć, Leposavić
SCIENTIFIC REVIEW ARTICLE

doi: $10.5937 /$ ekonomika2002063M

Received: December, 21. 2019.

Accepted: February, 14. 2020.

\title{
THE CAUSALITY OF ENTREPRENEURIAL MOTIVATION AMONG THE YOUNG AND THE OBSERVED AMBIENT OBSTACLES
}

\begin{abstract}
The identification of opportunities in the environment and, after that, the creation of ideas have the main role in starting an entrepreneurial process. The research field of this paper includes the subjective experience of ambient opportunities for the development of an entrepreneurial initiative by the young people who have become familiar with the importance of entrepreneurship through secondary and higher education in Serbia. In this paper, the authors pose the question whether the perception of ambient conditions, i.e. the observed ratio of opportunities and obstacles, will have an impact on the development of entrepreneurial motivation amongst young people. From their perception of the business environment and the aggravating circumstances they encounter, the motivation for inclusion in the entrepreneurial process either is born or disappears. If young people's perception implies that limiting factors are more dominant than stimulating ones are, the motivation for entering the entrepreneurial zone will be low, and vice versa. The data obtained through a survey were processed by applying descriptive statistics. The results obtained can serve to alleviate bottlenecks in young people's entrepreneurial education and knowledge of information, and in a potential more rigorous approach to the barriers that young people are faced with as well.
\end{abstract}

Keywords: entrepreneurship, motivation, the young, obstacles

JEL classification: J60, J62, A2, M2

\section{КАУЗАЛИТЕТ ПРЕДУЗЕТНИЧКЕ МОТИВАЦИЈЕ КОД МЛАДИХ И УОЧЕНИХ АМБИЈЕНТАЛНИХ ПРЕПРЕКА}

\section{Апстракт}

Главну улогу у покретању предузетничког прочеса има препознавање прилика у окружењу и након тога креирање идеја. Истраживачко поље овог рада обухвата субјективни доживљај амбијенталних прилика за развој предузетничке иницијативе од стране младих ьуди који су упознати са значајем предузетништва кроз средње и високо образовање у Србији. Аутори у овом раду постављају питање да ли ће периепџија амбијенталних услова,

\footnotetext{
${ }^{1}$ neimar.marija@gmail.com, ORCID ID 0000-0001-8499-7116

${ }^{2}$ sladjana.musikic@vpskp.edu.rs, ORCID ID 0000-0001-8251-423x

${ }^{3}$ zeljkodv@gmail.com, ORCID ID 0000-0001-8989-0094
} 
тј. уочени ращио прилика и препрека има утицаја за на развој предузетничке и мотивације код младих. Из юихове периепџије пословног окружења и отежавајућих околности са којима се сусрећу рађа се или нестаје мотивација за укључење у предузетнички процес. Уколико је перцепчија младих да су ограничавајући фактори доминантнији од стимулишућих, мотиващија за улаз у предузетничку зону ће бити ниска и обратно. Подаци добијени анкетом су обрађени дескриптивном статистиком. Добијени резултати могу служити за ублажавање уских грла у предузетничкој едукацији и информисаности младих као и у евентуалном ригорознијем приступу баријерама са којима се млади суочавају.

Кључне речи: предузетништво, мотивација, млади, препреке

\section{Introduction}

Understanding entrepreneurship as a process can by no means be complete and relevant unless the motivational aspect of these activities is explained (Ventakatamaran et al. 2012). Motivation is influenced by factors from the environment and the psychological underlying concept of an individual. According to many studies, the psychological characteristic of the individuals included in the entrepreneurial process primarily determines the success of such an undertaking (Baumol, 1990; Locke, 1996; Stewart \& Roth, 2001). In spite of this focus on the entrepreneur's psychological characteristics, the external environment seems to slowly start prevailing as the basis for understanding business startups (Taomina, Mei Lao Sammi, 2007). Undoubtedly, the national economy, with its characteristic ambient conditions, generates entrepreneurial conditions, and simultaneously entrepreneurial undertakings. Different levels of the development of a country exert a different influence on the entrepreneurial initiative. So, the environment models entrepreneurial behavior and represents the basic and initial impulse of entrepreneurial behavior (Levi \& Autio, 2008). Other studies highlight a different order of matters - as a psychological characteristic, motivation encourages the entrepreneur to take the initial step, while impulses from the environment influence the entrepreneur's potential in a later phase (Kirkwood, 2009).

A higher level of direct support to young entrepreneurs will have an influence on a larger cope of the entrepreneurial process. National economic conditions have an influence on the creation of business opportunities for entrepreneurs, whereas direct support (capital availability, state subsidies, etc.) affect the strengthening of the exploitation of the same (Davidsson, 1989). General national conditions imply the factors impacting the business activities in a general sense, and they may be as follows: institutions, the infrastructure, macroeconomic stability, elementary and higher education, the market efficiency and size, the availability of technologies. Special conditions include the government policy through programs and funding, the openness of the market (Levi \&Autio, 2008), and so on. The subjective perception of ambient conditions include the dynamism of the economy, the consumer structure and competition (Pelham \& Wilson, 1995).

So, a favorable environment influences the strengthening of the motivation of a potential entrepreneur towards success and starting a business, and motivation appears through the ability of perceiving opportunities (a favorable stimulus from the 
environment) and through the applied wish to take advantage of such an opportunity. That causality is the subject matter of the research conducted in this paper. The cause-and-effect relationship between the perception of ambient opportunities of the undergraduate students of the economic orientation and their motivation for entering the entrepreneurial zone is sought. The paper is divided into two parts. In the first part, institutional barriers to entrepreneurship among the young in Serbia are presented. In the second part, the answers received from the students regarding their perception of the barriers, as well as their motivation, are analyzed. Those answers are compared by the method of descriptive statistics.

With a bad legacy, the business environment for the business doing of young people in Serbia requires a detailed systematic approach to the creation and stimulation of the dynamic development of entrepreneurship since entrepreneurship exerts an influence on designing new organizations (Erić-Nielsen, J. et al. 2019). Serbia did not continue to participate in the Global Monitoring of Entrepreneurship (it stopped participating in 2009), which is conducted by the consortium of universities from about 65 countries, with the aim of analyzing the countries' entrepreneurial activities annually. For that reason, we are unable to monitor the degree of the development of entrepreneurship, make comparisons, appraise entrepreneurs' motivation (Petrović \& Leković, 2019). This paper should make one part of that gap complete.

\section{Observed Obstacles to Entrepreneurship Amongst the Young in Serbia}

Certain obstacles that young entrepreneurs are faced with are much bigger, more pronounced and more intensive for them than they are for adults. First, the burdening bureaucracy and the unstable regulatory framework, i.e. the laws and bylaws supporting the development of entrepreneurship, are susceptible to frequent changes. Young, potential entrepreneurs have no time and no money to interpret numerous legal changes, which on its part creates the first obstacle of uncertainty in the business environment for young people. The legal framework is very important because of young entrepreneurs being very easily "pushed" from the market. Young people have no picture of solvent business entities, become indebted due to bad debts, and judicial proceedings are longlasting and expensive. Businesses are often dissolved too early (Leković \& Barber, 2012).

Second, the problem of financing young entrepreneurs and a lack of information about available funding programs unfavorably influence the business efficiency of the young. Own assets are still the basic source of financing. Own assets are a source accounting for $85 \%$ of the total funding of firms in Serbia; $8 \%$ originate from banks, whereas $68 \%$ of firms do not use the sources of external financing at all (Bobić, 2017). The banking sector does not find young people at the beginning of their business doing attractive because their business is risky and unstable. The majority of young entrepreneurs see a lack of financial assets as the biggest obstacle that makes them unconfident about starting their business.

Third, there is the problem of a lack of appropriate, timely information regarding business doing, lying in entrepreneurs' insufficient entrepreneurial culture, philosophy and skill to obtain the needed information. The institutions of the state must, on their part, provide the needed capacities and motivation for conveying necessary knowledge 
to young entrepreneurs. There are a large number of regulations on the establishment and starting a small business (156 laws and over 250 bylaws), which are difficult to interpret and, later, monitor. It is difficult for young entrepreneurs to observe the advantages and threats posed to them out of the procedure for establishment.

Fourth, there are training programs for starting a small business, but, on the other hand, there are no programs for further running of the business. There is a lack of programs for the development of business doing skills, the development of an idea, finding business clients, product development. For example, the National Employment Service (NES) organizes training courses for the procedure for the registration of small firms, writing a business plan, but all of it is at a theoretical level, deprived of practical examples, conversations with successful entrepreneurs from a local community and environment. The examples evident in international studies lack an analysis of the influence of some of the examples of the development of young people's entrepreneurship on small business in Serbia. How to adapt the examples of the development of young people's entrepreneurship to the conditions of business doing, culture in our country, and how to implement and monitor the effects of a program and support after the first phase of starting a small business, too, is a very important question requiring a systematic, coordinated institutional approach to solving.

Fifth, Serbia pays little attention to the mentor's work that is important to the business doing of the young. Mentorship is short-term, intended for concrete cases, without later support in the development of the started business. The Development Agency of Serbia (DAS) and the National Employment Service (NES) deal with mentorship in Serbia. Both institutions conduct the programs that are short-term, timelimited irrespective of the obtained results of the conducted program, inflexible, not adapted to the needs of the program users. No good coordination of the institutions implementing support to young entrepreneurs and training courses in self-employment at the local level has been established. Thus, the effect of joint action and helping is missing. In the beginning, it is difficult for young people to observe the advantages and disadvantages of the establishment of a small firm, and they receive information about that from their families and friends. Quality mentorship is necessary in this phase, and the mentor will be interested in monitoring the further development of a young entrepreneur and give support.

\section{Research Goals, Tasks, and Hypotheses}

Young people's entrepreneurship is a dominant factor in a potential decrease in unemployment. Young people need to perceive entrepreneurship as a chance of employment, a career opportunity. The way young people treat entrepreneurship is also important as an indication of the potential of this sector for a potential growth. An insight into their understanding of, first of all, the notion of entrepreneurship, then the perception of the environment and existent limitations, may be a good information base. The results obtained may serve to mitigate bottlenecks in entrepreneurial education and young people's being informed, and in a potential more rigorous approach to the barriers that young people are faced with as well. Their motivation for inclusion in the entrepreneurial process is either born or disappears from their perception of the business environment and the aggravating circumstances they come across. Should young people perceive that the limiting factors are more dominant than stimulating ones, their motivation for entering the entrepreneurial zone will be low, and vice versa. Simultaneously, it is also 
the hypothesis we start from in our research. In the research, we start from the basic hypothesis that there is no significant connectedness between the perception of the conditions for entrepreneurship in the country and the motivation for their inclusion in the entrepreneurial process. Out of the basic hypothesis set in this way, several individual hypotheses arise. The indirect indicator used is the sex and the education level; so, the difference in the answers received from the respondents according to the sex and the school they attend (a secondary school or a university) was considered.

Based on the defined goal and subject matter of the research, the following research tasks were singled out:

determine whether young people have some idea for engaging in private business;

- if they do, determine their motives for starting a business;

- determine the respondents' assessment of the conditions for the development of entrepreneurship in Serbia;

determine the respondents' assessment of the obstacles to starting a business; determine whether the respondents have the intention to start their own business or not.

\section{Research Method, Techniques, and Instruments}

In order to check the starting hypotheses in this research study, the descriptiveanalytical method was used to describe, value and interpret the collected data (Bakovljev, 1997), and within it - the ANOVA method and the procedure called the $\chi 2$ test, used in the majority of cases if qualitative data are concerned. The basic research data can be measurement values, but only their frequencies are entered into the $\chi 2$ test. This is a very practical test which may serve once we want to determine whether some obtained (perceived) frequencies deviate from the frequencies that would be expected under a certain hypothesis or not. The research was done by applying the surveying technique, which was implemented through the instrument of a survey questionnaire. The data obtained were processed both qualitatively and quantitatively, whereas the results are shown textually and tabularly.

\section{Research Sample and Organization}

The conducted survey included a total of 333 respondents, of whom $63.7 \%$ accounted for the students of the Business Belgrade Business Academy for Applied studies, and 121 (i.e. 36.3\%) were the pupils of the Vocational Secondary School for Economics and Trade. The respondents' age ranged from $16(1.8 \%)$ to 25 years of age $(0.9 \%)$. The largest number of the respondents were 18 years old $(20.7 \%)$, only to be followed by those 20 years old $(18.0 \%)$ and 21 years old $16.8 \%$ ). The survey was conducted on the territory of Jagodina, Dimitrovgrad, Blace and Stara Pazova. The examination was finished in October 2018. The respondents had enough time to answer the questions posed. The questions were of the closed-ended type. The surveying was anonymous and the same was performed via a paper questionnaire. Although the sample has certain elements of a stratified quota sample, it was basically suitable (Kulić, 1998). The respondents had enough time to answer the questions posed. The questions were of 
the closed-ended type. The surveying was anonymous and it was performed via a paper questionnaire. The defined questions the respondents answered are as follows:

1. Have you got an idea for engaging in your own business?

2. What are your motives for engaging in your own business?

3. Are there conditions for business in Serbia?

4. In your opinion, are there obstacles to engaging in entrepreneurship in Serbia?

5. Are you seriously thinking of starting your own business?

The first four questions had a possibility of being attributed an amphibolous answer ("yes" or "no"), whereas the question about the conditions for engaging in entrepreneurship is of a Likert type.

\section{Results of the Statistical Analysis}

a) Have you got an idea for engaging in your own business?

The completion of secondary school or university education is a step towards entering the labor market. How ready the young respondents are to integrate into the business environment can be seen through their answers to the question whether they have an idea for starting their own business or not.

Figure 1: Have you got an idea for engaging in your own business?

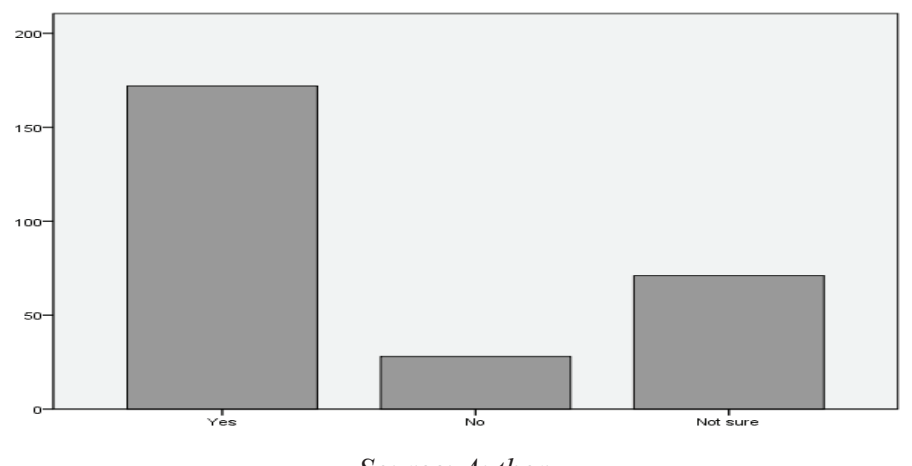

Source: Author

The figure reflecting whether the young have an idea for starting a new business or not is dominant. As many as $63.9 \%$ of the respondents answered positively. The least percentage, namely $10.11 \%$ of them, had no idea for starting a new business. It was further considered whether there was a significant difference between the respondents of the male and the female sexes, and those having secondary school and university education, with respect to their having an idea for engaging in business.

Given the fact that the value of the statistics of the test is $p=0.98$, i.e. greater than 0.05 , no statistically significant difference was found with respect to the idea for starting own business according to the education level by the method of the $\chi 2$ test. It is possible to conclude that the respondents' years of age are not an obstacle to creativity and the wish to succeed independently. The difference in the sexes with respect to this question has a greater and significant influence, $\chi^{2}(1, \mathrm{n}=333)=0.00, \mathrm{p}<0.05$. 
b) How familiar are you with the stimulating measures of the Republic of Serbia?

Table 1. The respondents' familiarity with the active measures of the RoS

\begin{tabular}{|c|c|c|c|}
\hline $\begin{array}{c}\text { Familiar with stimulating } \\
\text { measures in the RoS }\end{array}$ & Number & $\%$ & Cumulative \% \\
\hline Not familiar at all & 80 & 29.6 & 29.6 \\
\hline Partly familiar & 172 & 63.7 & 93.3 \\
\hline Familiar & 18 & 6.7 & 100.0 \\
\hline$\Sigma$ & 270 & 100.0 & \\
\hline
\end{tabular}

Source: Author

The answers show that only $6.7 \%$ of the respondents are familiar with the stimulating measures for young people, and as many as $63.7 \%$ are partly familiar. The data showing that a larger number of the respondents are not familiar at all with stimulating measures for young people is concerning. Here, the statistics indicate a shortcoming of our educational system when the question about entrepreneurial learning is concerned.

Similar results were obtained when respondents answered the question whether they had participated in Youth Entrepreneurship projects, which were implemented in order to develop an entrepreneurial culture. The results are as follows. Out of 269 responses, $32(11.9 \%)$ participated in one of the projects. Even 61.3 did not participate in the project even though it was informed, while $26.8 \%$ had never heard of the project.

c) What are your motives for engaging in your own business?

Figure 2: The motives of students for engaging in their own business

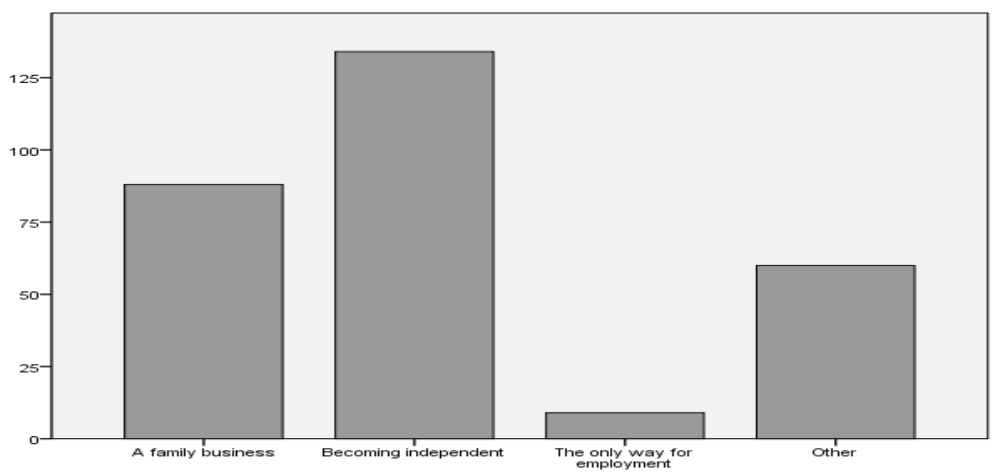

Source: Author

Figure 2 allows us to notice that employment is the last reason that would bestir the young respondents to engage themselves in small business. The method of the $\chi 2$ test was used to examine whether there was a difference in the reasons for engaging in one's own business in relation to education, given the fact that $\mathrm{p}=0.038$, but with a weak intensity of the connection (0.18). The sex is not the significant factor that makes differences in the answers to the question of the reason for the respondents' engagement in private business. Other studies also have similar results: the finding suggest that both men and women are motivated in a similar way by a combination of the "push" and "pull” factors (Hasni che Ismail. 2011). 


\section{d) Are there conditions for engaging in entrepreneurship in Serbia?}

This question was meant to make the respondents recognize the business environment in which they live and where they will work. Entrepreneurship in schools has the aim to make the attendees familiar with the options offered with respect to employment, the recognition of a favorable climate for the development of business, creativity and innovativeness in finding one's way in the given circumstances, so that the respondents can be considered as capable of reliably answering the posed question.

Figure 3: Are there conditions for engaging in entrepreneurship in Serbia?

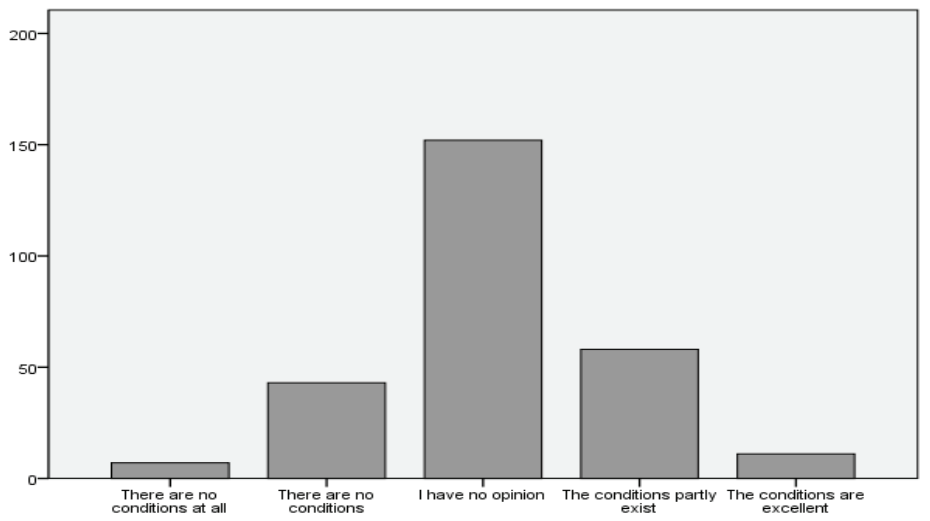

Source: Author

The respondents included in this survey, i.e. 55.8\% of them, answered that they had no opinion about the existence of the conditions for business in Serbia. A total of $21.6 \%$ of the respondents answered that the conditions partly existed, whereas $16 \%$ answered that there were no conditions for starting a small business. Such a result with a high percentage of the respondents who provided the answer that they had no opinion about the conditions for engaging in business in the country already shows a certain indifference in the young towards impulses from the environment. The second reason for such results can be sought in a lack of applied entrepreneurial education. The further analysis examined whether there was a difference in the respondents' opinions on the existence of the conditions for the development of private business classified according to the sex and the education level. No statistically significant difference was found. Although the analysis of the monofactorial variance shows that there is no significant difference at the statistical level in the frequencies of these answers, the range in the answer is tendentious with possible significant differences on a bigger sample.

e) In your opinion, are there obstacles to engaging in entrepreneurship in Serbia?

The previous question is connected with the question of the obstacles to engaging in entrepreneurship in Serbia. The results are shown in the table below. A total of 55.3\% considered that there were obstacles to small business, whereas $18.9 \%$ considered that there were no obstacles. The answers given by young men and women were identical, without bigger oscillations. 
Table 2. In your opinion, are there obstacles to engaging in entrepreneurship in Serbia?

\begin{tabular}{|l|l|l|l|}
\hline & Total number & $\%$ & Cumulative \% \\
\hline Yes & 73 & 55.3 & 55.3 \\
\hline $\mathrm{Ne}$ & 25 & 18.9 & 74.2 \\
\hline I am not sure & 34 & 25.8 & \\
\hline$\Sigma$ & 132 & 100.0 & 100.0 \\
\hline
\end{tabular}

Source: Author

No significant difference was determined by applying the $\chi 2$ test in the perception of obstacles to engaging in entrepreneurship between the sexes $(p=0.77)$. The perception of both sexes with respect to the obstacles to engaging in private business is identical.

Table 3. In your opinion, are there any less barriers to entrepreneurship abroad?

\begin{tabular}{|c|c|c|c|}
\hline & Total number & $\%$ & Cumulative $\%$ \\
\hline Yes & 204 & 62,0 & 62,0 \\
\hline No & 63 & 19,1 & 81,2 \\
\hline I am not sure & 62 & 18,8 & \\
\hline$\Sigma$ & 329 & 100,0 & 100,0 \\
\hline
\end{tabular}

Source:Author

The majority of respondents $(62 \%)$ rated the conditions for the development of entrepreneurship abroad more favorable than in Serbia. When asked which country offers the best conditions for a business career, $35 \%$ of young respondents answered that it was Germany, then Switzerland - 9.6\%, America - 9.3\%, Scandinavian countries (Sweden - $6.9 \%$ and Norway (5.7\%), Austria $-2.7 \%$. Germany is a country that has developed support programs for new entrepreneurial ideas, business incubators, favorable loans for young entrepreneurs, free business premises to use for small businesses. Our support and assistance could benefit from and adapt some of these youth assistance programs.

\section{f) Are you seriously thinking of starting your own business?}

Young women are readier than young men to start their own business, according to the data obtained in Figure 4 (47\% of women against $30 \%$ of unconfident men). The $\chi 2$ test method confirms the finding that there is a difference between the sexes when their respective decisiveness to start their own business is concerned. The value obtained is $\mathrm{p}=0.01$, but accompanied by low correlation, i.e. a weak intensity of the connection between the two variables (0.2) according to Cramer's Indicator V (Cramer's V). The result as this one can be attributed to by the psychological underlying concept in young women who are not prone to risk. 
Figure 4. Are you seriously thinking of starting your own business?

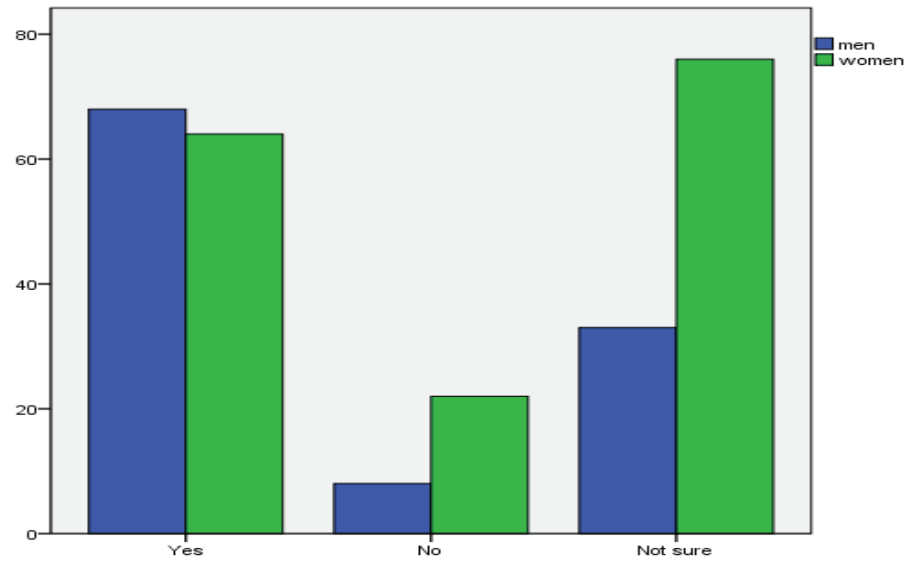

Source: Author

The method of the monofactorial analysis of a variance was used to examine whether there is a significant difference in the answers given by the respondents to the question "Are you seriously thinking of starting your own business" and the assessment of the conditions for the development of business in Serbia. No significant difference between the mean variables was found, i.e. the variances show that there is no significant difference at the statistical level in the frequencies of these answers. There are no sufficient pieces of evidence on our statistical sample that the conditions for business doing, the perception of ambient obstacles by the young respondents, had an influence on decisiveness to start a private business.

\section{Conclusion}

A high percentage of the respondents in this survey, i.e. $56 \%$ of them, answered that they had no opinion about the existence of the conditions for business in Serbia; only $6.7 \%$ of the respondents are familiar with the stimulating measures for young entrepreneurs; only $11.9 \%$ participated in Youth Entrepreneurship projects. This outcome can lead towards a conclusion of the indifference in the young towards the influences from the environment or the weakness of applied entrepreneurial education. The method of the monofactorial analysis of a variance was used to examine whether there was a significant difference in the respondents' answers or not to the question "Are you thinking of starting your own business?" and the assessments of the "conditions for the development of business in Serbia." No significant difference between the mean variables was found. We cannot prove that perception of ambient obstacles by the young respondents, had an influence on decisiveness to start a private business. We assume that abovementioned indifference in the young towards the influences from the environment influenced the ultimate outcome.

The obtained result also confirms the data that the young are intensively thinking of their business in spite of the obstacles they perceive. Namely, as many as $63.9 \%$ of the respondents positively answered the question whether they had an idea for starting a business or not. In the answers to this question, there is a difference between the sexes, 
and it has a significant influence, $p=0.00$, so $p<0.05$. The result like this can be attributed to by the psychological underlying concept of young women not prone to risk.

\section{References}

Bakovljev, M. (1997). Osnovi metodologije pedagoških istraživanja, Beograd: Naučna knjiga Baumol, W. (1990). Entrepreneurship: Productive, Unproductive and Destructive, Journal of Political Economics, No. 98, p.893

Bobić, D. (2017). Mapiranje prepreka za preduzetništvo mladih, CEVES, Centar za visoke ekonomske studije, Beograd

Hasni che Ismail.che (2011). An Exploratory Study of Motivational Factors on Women Entrepreneurship Venturing in Malaysia. Business and Economic Research. 2. 10.5296/ber.v2i1.1434

Davidsson, P. (1989). Continued entrepreneurship and small firm growth. Stockholm School of Economics, The Economic Research Institute

Erić-Nielsen,J et al. (2019). The challenges of managing the entrepreneurial organization, Ekonomika, vol. 65, iss. 2, pp. 87-98

Gavrić, G., Simonović, Z., \& Lazović, K. (2015). Knowledge as a factor of survival and competitiveness in modern business. Anali Ekonomskog fakulteta u Subotici, (33), pp. 389-400.

Jovičić A., Đokić A.,Denić N., (2019) Ekonomsko-ekološki aspekti održivog razvoja preduzeća. Ecologica, Vol. 26, No 93, pp 26-30.

Kirkwood, J. (2009). Motivational factors in a push-pull theory of entrepreneurship. Gender in Management: An International Journal, Vol. 24 Issue: 5, pp.346-364, https://doi.org/10.1108/17542410910968805

Kulić, R. (1998). Sadržaj rada i obrazovanje, Andragoška biblioteka, Zavod za udžbenike i nastavna sredstva, Beograd

Lekovic, B., Berber, N., (2012). Barrier to entrepreneurship in Autonomous Province of Vojvodina: Research from aspects of age and gender. Employment Education and Entrepreneurship, pp. 267-286

Leković, B. (2015). Kauzalitet preduzetničkog ponašanja, faktora uspešnosti preduzetničkog poduhvata $i$ ambijentalnih uslova. (doktorska disertacija), Ekonomski fakultet u Subotici, Univerzitet u Novom Sadu

Levie, J., Autio, E. (2008). A theoretical grounding and test of the Gem model. Small Business Economics, Vol. 31 (3), pp. 235-263

Locke, E. (1996). Motivation through conscious goal setting. Applied \& Preventive Psychology, No. 5, pp.117-124

Pelham, A. M., Wilson, D. T. (1995), A longitudinal study of the impact of market structure, firm structure, strategy, and market orientation culture on dimensions of smallfirm performance. Journal of the academy of marketing science, vol. 24(1), pp. 27-43

Petrović, M., Leković, B. (2019). Characteristics of ambitious entrepreneurs in Southeast Europe region: High-growth expectation concept. Anali Ekonomskog fakulteta $u$ Subotici, iss. 41, pp. 55-66 
Stewart, W. H., Roth, P. L. (2001). Risk propensity differences between entrepreneurs and managers: A meta-analytic review. Journal of Applied Psychology, 86(1), pp. 145153

Taomina J.Kin \& Hyphen., Mei Lao Sammi. (2007). Measuring Chinese entrepreneurial motivation: Personality and environmental influences. International Journal of Entrepreneurial Behaviour \& Research, Vol. 13, Issue 4, pp. 200-221

Venkataraman, S., Sarasvathy, D. S., Dew, N., Foster, W. R., (2012). Reflections on the 2010 AMR decade award: whither the promise? Moving forward with entrepreneurship as a science of the artificial. Academy of Management Review, 37(1), pp.21-33, doi:10.5465/amr.2011.0079. 